\title{
"AN IRISH BOY HE MAY WELL BE BUT HE SPAK BRAID SCOTS WHEN HE COORTIT ME": SONG CONNECTIONS BETWEEN IRELAND AND SOUTH WEST SCOTLAND
}

\section{VALENTINA BOLD}

This survey paper makes a start at looking, through a series of specific examples, drawn from oral and printed song traditions. This paper looks at the song culture of South West Scotland and the way it relates to that of its near neighbour across the water, Ireland. The range of examples considers allows the writer to look at images from the nineteenth century to the present-many racist and unpleasant - and to show the influence of Irish area, more broadly, on both urban and rural Scottish musical and song traditions. The modern song culture of the area under consideration, in conclusion, bears lasting traces of Irish influence. This field would prove rewarding for further, in-depth research. Keywords: folksong; Ireland; Scotland; ethnicity.
Pregledni članek omogoča začetek analize niza značilnih primerov iz ustne in pisne pesemske tradicije. Prinaša pogled na pesemski izročili jugozahodne Škotske in sosednje Irske. Vrsta primerov je avtorici omogočila, da si je ogledala upodobitve ljudi-nekatere rasistične in neprijetne - in v širšem smislu pokazala vplive irske pesemske tradicije, tako na urbano kot ruralno škotsko glasbeno izročilo. V sklepu ugotavlja, da "sodobna" pesemska kultura raziskanega območja nosi sledove irskega vpliva. To področje bi bilo vredno nadaljnjih poglobljenih raziskav.

Ključne besede: ljudska pesem, Irska, Škotska, etničnost.

\section{INTRODUCTION}

This paper considers connections between the song cultures of Ireland and South West Scotland. To start I would like to quote a little from "The Irish Boy", as sung by Stravaig, in a version collected by Phyllis Martin in Wigtownshire from Joan Cron, arranged and sung by Stravaig and Billy Henderson:

There sits a bird in yonder tree,

Some say he's blind and cannot see,

Oh how I wish that bird was me,

Since my true love has left me.

And it's oh what a foolish young girl was I,

To fall in love with an Irish boy,

An Irish boy he may well be,

But he spoke braid Scots when he courted me. (Stravaig 2000)

I wanted to start with this song because it epitomizes many of the points I want to make. Of 
course, it is in some ways a standard, with its floating stanzas, like that first one. However, these are customized with images associated with the Irish in South West Scotland (by which I mean primarily Dumfries and Galloway, and its closest city, Glasgow).

The Irish boy here is the bold deceiver, exhibiting trans-cultural behaviour which is similar to that of the "female cabin boys" who cross gender to be with their lovers at sea. He is able to "pass" as Scottish by dint of the language shared between Ireland and Scots, spoken with a "Galloway Irish" accent. As Phyllis told me, the Boy must have come from Larne, that still can be found about the Stranraer area. Beautiful accent. ${ }^{1}$ Because of the language dimension, then, this song has particular resonance for South West Scotland.

I would like to thank Phyllis and her husband, Billy, of "Linkum Doddie", for help with this paper. Thanks are due too to Nick Spencer of "Two Left Feet" and, formerly, "Black Eyed Biddy", who freely shared his musical expertise with me. Although I will not have the space here to discuss musical exchanges, it is worth mentioning that the South West's instrumental scene is hugely influenced by Ireland, particularly recently through the availability of recordings. Of course, musicians and singers go both ways to perform in festivals and, like the Martins, to teach workshops. Incidentally, the South West did not undergo the same reaction against Irish music as in some Scottish circles in the late seventies and eighties, and which Peter Symon has profiled (Symon 1997: 207, 208).

Here, I want to do two things: to give an overview of song contacts between Ireland and South West Scotland and to look at images of cross-cultural contacts within selected nineteenth century broadsides. This is very much work in progress. For the time being, too, I am using the term "Irish" the way South West singers usually do: to indicate a theme, or a place of origin, identified with Ireland. I do not want to define precisely constitutes "Irish song" - others have done this far better than I could, and are far more knowledgeable about the subject (O’Boyle 1976).

\section{IRELAND AND SOUTH WEST SCOTLAND}

In the past, attention has tended to focus on the urban centre of Glasgow as a nexus for connections between Ireland and Scotland. There is a very long tradition, too, of Irish settlement in Scotland's South West. By the nineteenth century Wigtownshire, in particular, was home to many Irish people. The minister of Stranraer, mid-century, commented on the "wretchedness" of the population [...] who are mostly of the lower orders of the Irish. He added the number of Irish families that every year take up their abode in this place is almost incredible. The Account estimated one fifth of the population of Wigtownshire were first

1 All quotations from Phyllis and Billy Martin are from a transcript of a discussion with them, by Valentina Bold, in Dalbeattie, during December 2007. The comments on music draw on discussions with Nick Spencer, during July 2008. These quotations appear with the kind permission of Phyllis and Billy Martin, and of Nick Spencer. 
or second generation Irish. Similarly, the Report of the Royal Commission on Scottish Poor Laws estimated 15\% of Wigtownshire was Irish.

Equally, Northern Ireland provided rich pickings for Galloway: many aristocrats, like the Stair family, benefitted from the Plantation of Ulster; there were also links between Covenanters exiled from the area and Northern Ireland. On a more mundane level, there were numerous trading contacts. Robert Heron, writing in 1792, described a vessel at Cairnryan, coming from Bangor in Ulster to land cattle for droving to England (see Swift and Gilley 1985; McCulloch 2000: 43, 44, 73, 471, 472; NSA, Wigtownshire and Kirkcudbright and Campbell, Owners and Occupiers, cited McCulloch: 471; see, too, Donnachie and Macleod 1974: 31, 52; Robert Heron Observations made in a Journey thr' the Western Counties of Scotland in the autumn of 1792 (1793) cited Donnachie and Macleod: $82,105,106)$.

In living memory, too, there are recollections of seasonal workers going over to Scotland for harvest, many of them from Donegal and Mayo. The Martins remember this in the 40s and 50s. Many Irish visitors, like Billy Martin's uncle Francis, a joiner, married local girls. Francis's brother in law would bring over a squad of tattie-howkers, or potato pickers, for the annual harvest. Irish families, too, like the Boyles, the Finnegans and the O'Neills, were, and still are, well known in the area (Swift and Gilley 1985). ${ }^{2}$

\section{IRISH SONGS}

Phyllis Martin came from a musical family of nine children; they enjoyed large family gatherings with her sister dancing and playing the piano, and Phyllis playing the accordeon. In this context, Irish songs played a big part:

Irish songs played a big part in our lives because we learned more Irish stuff than we did Scottish. Ma father sang Irish songs, my mother sang Irish songs [...] Ma father sang, "The Rose of Tralee", "The Boys of Armagh", things like that. Ma mother sang more love songs [....] "Irish Boy" was her one.

Phyllis is convinced that the style of singing in South West Scotland has been influenced by Irish idioms. On a small point, the last lines of songs are often spoken in this area; on a larger one, there are common styles of songs. Phyllis told me: when Billy first startet to sing, it was always the Irish humorous kind of songs that he would sing, that he'd picked up from the Irish tattie howkers - until he found the bothy ballads. Billy has fond memories of the Irish tattie howkers, who came for six weeks to Wigtownshire each autumn. As well as exchanging songs while they worked in the fields, they enjoyed singing at night:

Sunday night was ceilidh night. Ma uncle's brother-in-law, he run the

2 A phone book search today shows that these names are still well represented-there are 32 O'Neill families (with various spellings), in the area along with 14 Boyles and 4 Finnegans. Several of these are from Whithorn and the Isle of Whithorn, where Billy Martin grew up. 
squad an brought his over, and they always insisted, they always looked for a fiddler, or a flute player, for a Sunday night was ceilidh night. They went to mass at six o' clock, mass finished, and then they got their carry out and took it back and had a ceilidh till six o'clock in the morning and then went pickin tatties again! That wis it, but Sunday night was always ceilidh night.

Irish songs were also a large part of the Saturday night sing song in Billy's family, when his uncles, aunts and friends came over after the pubs closed (then at ten o'clock). There might be fifty people in the living room for a Saturday night sing song. Later, travelling in Ireland, the Martins often recognized songs from those days, as Billy told me: when we were over in Donegal [...] some of the songs over there were just songs you heard in the house, you know? [smiling] They were just songs that were sung all the time. Phyllis agreed, adding that sometimes there were slight variations:

It was nice to go over to Ireland and hear some of the songs that ma mother sang, but ma mother sang it slightly different. A lot of the wording had changed. A would say that it had got more polite as it moved west. Like that one, "Go an leave me". They sing "Ifyou think I've proved unworthy". My mother'd sing "Ifyou think I'm so unworthy" which to me makes mair sense. You wouldnae say to somebody "If you think I've proved unworthy", you'd say "Well, if you think I'm so unworthy, bugger off!

Perhaps the Scottish version is a little more modern, but this is one example, perhaps, of different stylistic preferences.

Intriguingly, too, the sectarianism of some songs seems to have been forgotten in the relatively safe context of the coastal South West, at least in the forties and fifties. Billy made this point quite succinctly to me:

Most of my uncle's squad were Orangemen but that didnae mean [anything]. The ones who sang political songs were Irish ones, and they were singing Orange songs. Singin airs, they just sung along. You couldnae feel any friction. They were people there to enjoy thirselves. They used tae sing thegither a the time and sing both sides of the divide, you know? [...] Political songs were sung and nobody bothered about it, you know, "We cannae sing that", you know, "It's no politically correct tae sing that". Ye sung it. It wis just a song to be sung and that was aw it was.

Phyllis added an explanation: it would be the music not the content of the song. It would actually be the camaraderie of sittin there, singin together and enjoyin the night and there would be no friction. Perhaps there are parallels, here, to the non-sectarian activities in the folk revival of the 1960s in Belfast, as May McCann has profiled: this is certainly an area which would repay further investigation (McCann 1995). 


\section{ETHNIC STEREOTYPING}

On a less pleasant note, in the nineteenth century, particularly in the city setting of Glasgow, Irish people in songs seem to have had a certain "outcast" status. As M.A.G. Oे Tuathaig has written: a stereotype of the brutalized 'Paddy' was formed [...] intemperate, improvident, violent, totally innocent of any notions of hygeine, mendacious and undependable - not so much a lovable rogue as a menacing savage (Ò Tuathaig: 22). Sadly, this image is found in many of the broadsides produced in the Glasgow Saltmarket, and known in the South West of Scotland. Most of my examples are from Special Collections at Glasgow University. Several are in the digitised Murray collection (Glasgow Broadside Ballads).

Some of these texts are relatively mild and comical, like "Dog Tray" (Nd), and "The raal ould Irish gintleman" (Nd): I'll sing you a dacent song, that was made by Paddy's pate,/ Of a raal ould Irish Gintleman who had a fine estate. However, others are more offensive, no doubt reflecting the nineteenth century prejudices which are below the surface in "The Irish Boy". Some of these are suggested, for instance in The Report on the State of the Irish Poor in Great Britain (1836). There, high ranking South West Scottish policeman express the opinion that Irish people are, by their very nature, of a criminal disposition (quoted Swift 2002: 104, 105).

Often the broadside Irishman is a drunkard and a rogue, often in a Scottish setting or with a Scottish link. "Mick the Watchman" (Nd), for instance, presides over a raucous party in the slums of Glasgow, ending up in the Duke Street prison for sixty days. "William Hill" forges Bank of Scotland notes-John Moulden has written about this broadside in detail (Moulden 2007). In “O' Connor's Farewell” (Nd), printed in Glasgow, Dinnes Connor from Castle Dawson is transported. His lover's father entrapped him into eloping with his lover to Scotland: the only crime I committed for love.

Here the Irishman becomes equivalent to the Latin lover to the nineteenth century Scot: a dangerous tempter. He has shades of the sexually active Highlander who, in song at least, had become sanitized in the post-Jacobite era. In fact, as we will see in a moment, the image of the Highlander and Irishman is sometimes conflated in song. Irish and Scottish rogues sometimes step out together. In "Sawny and Teague", for instance, A bonny Scots lad, and an Irish dear-joy engage in a series of comic adventures: They neither before had seen a wind-mill, / Nor had they heard ever of any such name ("Sawny and Teague", nd).

\section{IRISH MEN AND SCOTTISH WOMEN IN LOVE}

Cross-cultural love affairs feature strongly feature in these broadsides, and it is them I want to turn to now. "The Irish Boy", which began with is, in many ways, typical of many of these like, for instance, "The Paddy Trick" (Nd). Published by the Poet's Box, in the Glasgow Saltmarket, in 1856, it tells the story, from the man's point of view, of deceiving 
a girl. He leaves for Scotland to find a sweetheart away from the fickle lassies of Ireland. In Scotland-in something of a double-edged compliment-the lassies are kind and free and, without causing a fuss, They'll take you to the barn, and make a bed among the stray, I Saying, if you will me undo, you'll marry me without delay.

Unfortunately, he causes a fair maid to be proved with child. Luckily, though, they have access to a plant called the little saving tree which makes her labour go aglee, or wrong. Revived, the maid offers to try the trick with you again and He took her in his arms the covering for to renew. Pregnant again, she tells Pat that if he denies the child, she'll have him jailed and force him to provide, Four pounds a-year. Paddy manages to avoid his wedding by running away, using the Paddy trick, to Ireland. It's a defamatory story, of course, but perhaps a salient warning to young women against transient men everywhere, like the "Lancashire Lads" who go abroad, or the other young men of song who will leave them in the lurch.

Equally, it is a song type that may have had influence in the South West. Phyllis Martin thinks that the local song from Galloway, "Creichan Hills", shows a slight Irish touch [...] in the tune and in the way that the song finishes. In "Creichan Hills", a "roving shepherd lad" from Barrhill, herding for Pete McGeough, courts Maggie Gaw. Her mother insists that they marry, but the lad, at the time his term ends, eschews their meeting place, and legs it back to Ayrshire: Sae fareweel unto the Creechan Hills, And to Hell wi Maggie Gaw! Phyllis herself sees an Irish humour as well as an Irish-sounding tune in this Wigtownshire song: A think the Irish have got a humour that's completely different tae anywhere else apart from up north in Aberdeenshire. They laugh at theirselves, and I think the Irish do as well. Although the hero here is Scottish, of course, he does have morals in common with Paddy the trickster.

"The beautiful Irishman" is a rather more vicious piece of ethnic stereotyping and I apologise for this. Also known as "The Terrible Irishman" in some versions, this is based on a poem by William Maginn, "The Irishman and the Lady" (see "The Beautiful Irishman" 1895). A stylish lady falls for an Irishman, Timothy Thady Mulligan: A wild, tremendous Irishman, / A tearing, swearing, thumping, bumping, / Ranting, roaring Irishman. The "beautiful", it soon becomes apparent, is sarcastic: His face was noways beautiful, / For with small-pox 'twas scarred across. This is a lump, a whisky devouring, he-rogue with his wonderful brogue, a fighting, rioting Irishman. He cracked the skulls of the men of Leith, I Just by wayo jollity, breaking hearts as he goes along.

To put myself, and the reader, into better spirits, after that stream of vituperation, it is, arguably, useful to consider something a little gentler: "The Irish Girl” (Nd), again from Glasgow, but this time presenting a beautiful young lady, Molly, in more conventional lyric form. This girl, with red and rosy cheeks, and coal black hair, is dressed in gold; the narrator sings to her, left behind while he is in Manchester. 


\section{IRISH MEN AND SCOTTISH HIGHLANDERS}

To show, too, the way in which the Irishman's image can be conflated with the Scottish Highlander, too, I would like to mention "Duncan Campbell “ $(\mathrm{Nd})$, who travels through Ireland and England under the name of bold Erin go Bragh. Wandering through Edinburgh he is stopped by a saucy policeman who accuses him of being Irish. He replies I am not a Paddy, though Ireland I have seen, I Nor am I a Paddy, though in Ireland I have been but the policeman is unconvinced:

I know you are a Pat by the cut of your hair,

But you all turn Scotsmen as soon as you come here;

You have left your own country for breaking the law,

We are seizing all strangers from Erin go Bragh.

Enraged, the Highlander hits the policeman with a blackthorn switch, and manages to escape pursuit by stealing a boat. The final lines show that this man thinks it no shame to be confused with an Irishman: For I'm from Argyllshire in the Highlands so braw, / But I ne'er took ill when called Erin go Bragh.

\section{TRAVELLING BETWEEN IRELAND AND SCOTLAND}

There are, of course, many songs of travel between the countries of Ireland and Scotland (a substantial sub category of songs of exile) and my next example, "Lovely Mourin Shore" $(\mathrm{Nd})$ is of this type. This narrator, having embarked from Derry Quay to Scotland, is living in Glasgow:

O Glasgow is a pretty place,

Wherein I do abide,

It's a lovely place I must confess,

On the flowing banks of the Clyde.

For they do incline to go neat and fine,

In rich apparel o'er.

But even there none can compare.

With the maids of Mourin Shore.

The experience here suggests that not all song Irishman are desirous of cross-cultural coupling; for many, as no doubt for their real-life counterparts, home would always be better.

My last example is really to give the Irish, metaphorically at least, the final word, with "The Sailor's Lamentation", set to the tune of the "Irish Boy". Here, the man has been deceived and the tables are turned: What a foolish boy was I, / To fall in love with a girl so coy. I like to think that he is Irish and that the Irish boy of the opening piece has, finally, been vindicated. 


\section{CONCLUSION}

Ultimately, I hope what I've done in this short piece is to start to indicate the ways in which broadsides, and more modern songs, indicate a wealth of cross-cultural connexions between South West Scotland and Ireland: some do this was suspicion, a few with admiration, but all in acknowledgement of a long-lasting relationship. In future, I would very much like to explore this further, perhaps in the context of looking at cross border musical contacts between South West Scotland and its neighbours, in Ireland and in Cumbria.

\section{REFERENCES AND SOURCES}

"The beautiful Irishman"

1895 (http://bartleby.com/246/110.html).

"Dog Tray"

No date [hereafter Nd] The Merry Songster. Seven Dials: Ryle \& Paul. Glasgow University Library Special Collections [hereafter GUL Sp Colls] Bh13-d.40 item 11.

"Duncan Campbell"

Nd In: Glasgow Broadside Ballads (http://www.gla.ac.uk/t4/dumfries/files/layer2/glasgow_broadside_ballads Mu23-y3:25 and the National Library of Scotland [hereafter NLS] L.C. Fol.70 (57b); http://www.nls.uk/broadsides/broadside.cfm/id/14986/criteria/duncan\%20campbell).

Donnachie, Ian and Innes Macleod (eds.)

1974 Old Galloway. London: David and Charles.

Glasgow Broadside Ballads

$\mathrm{Nd} \quad$ (http://www.gla.ac.uk/t4/dumfries/files/layer2/glasgow_broadside_ballads/).

"The Irish Girl"

$\mathrm{Nd} \quad$ In: Glasgow Broadside Ballads (http://www.gla.ac.uk/t4/dumfries/files/layer2/glasgow_broadside_ ballads Mu23-y3: 25 and NLS L.C.Fol.178.A.2(065) (http://www.nls.uk/broadsides/broadside. cfm/id/14830/criteria/the\%20irish\%20girl).

"Lovely Mourin Shore"

Nd NLS L.C.Fol.178.A.2(066) (http://www.nls.uk/broadsides/broadside.cfm/id/14831/criteria/ lovely\%20mourin\%20shore).

McCann, May

1995 Music and Politics in Ireland. The Specificity of the Folk Revival in Belfast. British Journal of Ethnomusicology 4: 51-75.

McCulloch, Andrew

2000 Galloway. A Land Apart. Edinburgh: Birlinn.

"Mick the Watchman"

$\mathrm{Nd}$ In: Glasgow Broadside Ballads (http://www.gla.ac.uk/t4/dumfries/files/layer2/glasgow_broadside_ballads Mu23-y3: 039). 
Moulden, John

2007 A True Song called Erin the Green, or William Hill, the Forger [...] Compiled from the best and most reliable records by John Moulden. Privately published.

O’Boyle, Sean

1976 The Irish Song. Dublin: Gilbert Dalton.

"O' Connor's Farewell"

Nd In: Glasgow Broadside Ballads (http://www.gla.ac.uk/t4/dumfries/files/layer2/glasgow_broadside_ballads Mu23-y3: 038).

Ò Tuathaig, M.A.G.

1985 The Irish in Nineteenth-Century Britain: Problems of Integration. In: Swift and Gilley 1985, 13-36.

"The Paddy Trick"

Nd In: Glasgow Broadside Ballads (http://www.gla.ac.uk/t4/dumfries/files/layer2/glasgow_broadside_ballads Mu23-y2: 012).

"The raal ould Irish gintleman"

Nd In: The Dublin lad's penny comic song book. Glasgow: no publisher [hereafter np]. GUL Sp Colls 2352 item 1.

"Sawny and Teague"

$\mathrm{Nd}$ In: King William and the plowman; or, industry rewarded. To which are added, Sawny and teague. A beau is but an ass. The power of love. Glasgow: J \& M. Robertson. Glasgow Sp Colls Bh13-d.3 item 34.

"The Sailor's Lamentation"

$\mathrm{Nd} \quad$ No publisher.

Stravaig

2000 Stravaig. Dumfries: Dumfries \& Galloway Arts Association.

Swift, Roger

2002 Irish Migrants in Britain 1815-1914. Cork: Cork University Press.

Swift, Roger and Sheridan Gilley (eds.)

1985 The Irish in the Victorian City. London: Croom Helm.

Symon, Peter

1997 Music and national identity in Scotland: a study of Jock Tamson's Bairns. Popular Music 16/2 (May): 203-216.

\section{"LAHKO, DA JE FANT Z IRSKE, A JE GOVORIL ODLIČNO ŠKOTSKO, KO MI JE DVORIL." \\ PESEMSKE POVEZAVE MED IRSKO IN JUGOZAHODNO ŠKOTSKO}

V razpravi avtorica ugotavlja, kako je na pesemsko kulturo jugozahodne Škotske vplivala Irska. Avtoričini viri vključujejo opažanja sodobnih raziskovalcev kulture (Phyllis in Billy Martin, 
Nick Spencer). Povezana so z navedki iz balad na letakih 19. stoletja, sčimer predstavlja še zgodovinski kontekst. Pregledno navaja družbene in ekonomske povezave med območjema in skǔ́a ugotoviti glasbene vplive Irske na jugovzhodno Škotsko po letu 1950. Razmišlja tudi o etničnih stereotipih, kakor so upodobljeni v pesemskih tradicijah obeh območij.

Irec se pojavlja na Škotskem v različnih preoblekah: kot prevarant, pijanec in slepar ter kot zapeljivec ( $v$ škotskem okolju, ali s škotsko povezavo, včasih tudi na podlagi škotskih stereotipov, ki veljajo za prebivalce škotskega višavja); medsebojna ljubezenska razmerja močno odsevajo tako iz balad na letakih kakor iz ustnega izrociila.

V sklepu avtorica povzame razlage o medkulturnih povezavah v pesemskem izročilu jugozahodne Škotske in Irske ter ugotavlja, da bi moralo biti to mejno območje deležno nadaljnjih poglobljenih raziskav.

Dr. Valentina Bold, Senior Lecturer, Convenor, M.Litt Scottish Cultural Heritage, University of Glasgow, Crichton University Campus, Dumfries DG1 4ZL, v.bold@crichton.gla.ac.uk 